\title{
THE ECONOMICS OF INFORMATION
}

TECHNOLOGY 
Also by Paul Jowett

PARTY STRATEGIES IN BRITAIN (with David Butler) 


\title{
The Economics of Information Technology
}

\author{
Paul Jowett \\ Research Associate of Templeton College, Oxford \\ and \\ Margaret Rothwell \\ Lecturer in Economics, Oxford Polytechnic
}

Palgrave Macmillan 
ISBN 978-1-349-18319-7 ISBN 978-1-349-18317-3 (eBook)

DOI 10.1007/978-1-349-18317-3

(C) Paul Jowett and Margaret Rothwell, 1986

Softcover reprint of the hardcover 1st edition 1986

All rights reserved. For information, write:

Scholarly \& Reference Division,

St. Martin's Press, Inc., 175 Fifth Avenue, New York, NY 10010

First published in the United States of America in 1986

ISBN 978-0-312-23434-8

Library of Congress Cataloging-in-Publication Data

Jowett, Paul.

The economics of information technology.

Bibliography: $p$.

Includes index.

1. Computer industry. 2. Telecommunication equipment industry. I. Rothwell, Margaret. II. Title.

HD9696 C62J68 $1986 \quad 338.4^{\prime} 7004 \quad 86-1268$

ISBN 978-0-312-23434-8 


\section{Contents}

List of Illustrations vi

List of Figures vii

List of Tables viii

Preface $\quad$ ix

Acknowledgements $\quad$ xi

Abbreviations and Acronyms xii

Introduction 1

1 Background to the Information Technology Race 5

2 The Japanese Challenge 21

3 The American Response 33

4 The European Response 47

5 The British Response 57

6 Strategies of European IT Companies in the 1980s 71

7 Conclusion $\quad 87$

$\begin{array}{ll}\text { Bibliography } & 95\end{array}$

$\begin{array}{ll}\text { Index } & 99\end{array}$ 


\section{List of Illustrations}

What the Europeans see?

24

He was so good at selling research that he landed a job with Nippon Mechanicals

DARPA's AI investment

If you want to publish, I can put you in touch with an industrial espionage outfit

And now we'll make a bomb out of Alvey 


\section{List of Figures}

1 The convergence of computers and communications 2

2 Worldwide shipments by US manufacturers 3

3 IT: output of products and systems, and balance of trade

4 Percentage values of American IC sales by end-use segment

5 Stages of Fifth Generation Computer R\&D

6 ESPRIT projects, 1984

7 Composition ratio trends in the production of major consumer electronics equipment 


\section{List of Tables}

1 Public policy towards information technology in the USA

2 Public policy towards information technology in the UK

3 Public policy towards information technology in Japan

4 Members of the FGCS Research and Planning Committee

5 SRC membership (April 1984)

6 SRC Centres of Excellence and Programme Centres

7 Joint ventures, joint agreements, and technical exchanges

8 Information-processing companies buy into one another

9 MCC members (October 1984)

10 ICL's joint ventures, 1980-4

11 Olivetti's venture capital investments, 1980-4

12 Collaboration entered into by Olivetti, 1980-4

13 French government grants and Thomson's collaborative ventures

14 Phillips' joint ventures and acquisitions, 1980-4

15 Thorn EMI's joint ventures and acquisitions, 1980-4

16 GEC's joint ventures, 1980-4

17 AEG-Telefunken's joint ventures, acquisitions, and disposals, 1980-4 


\section{Preface}

This book analyses the development of Information Technology (IT) at both the microeconomic and macroeconomic level. At the microeconomic level, individual firms, universities and research laboratories in Britain, Europe, the USA and Japan are the principal focus of attention, whereas, at the macroeconomic level, investigations are made and comparisons drawn between the countries' differing national efforts and the key role their governments have played in stimulating these. Whilst the scope of this book is broad, its objective is specific: to identify the principal economic determinants of success for companies and countries working in the field of IT, and to explain why certain companies and countries have performed better at times than others.

The reasons for writing a book on the economics of IT are many. The most obvious is that IT has become a major new, fiercely competitive, and rapidly changing world industry - one which has applications in all three traditional economic sectors (primary, secondary and tertiary), one which almost every developed (and to a certain extent underdeveloped) nation has sought to enter, and one whose strategic potential is immense. This in itself makes the IT industry a worthy subject for economic analysis.

Writing a book on such a broad and all-encompassing subject has not been easy. Because of the lack of any existing competent introduction to the subject, this book has a distinctly historical slant. Only by reviewing the origins and subsequent development of this new industry can one discern trends on the basis of which future projections about the industry's structure and strategic importance can be made. This book does not offer a complete history of the economics of IT. What it does is to select particular examples of the development of IT, from various countries, which illustrate most clearly the trends and determinants of success at that time. Thus, the reader is provided not with an historical summary, devoid of any economic theory, but with a stimulating and dynamic applied economic analysis of an exciting industry. 
No attempt has been made to relate this applied analysis directly to existing economic theory, and the reasons for this are twofold. Firstly, the traditional economic theory of entry barriers, collusion between rivals and the effect of technical change on market structure, neither accurately or adequately describes the dynamic IT industry. Secondly, the modification of existing, and development of new, theories, although of academic interest and importance, lies beyond the scope and objectives of this book, which is intended to appeal to as large an audience as possible, including non-specialists. In addition, no attempt has been made to investigate the present and future impact of IT on other sectors of the economy, since a task as difficult and complex as this would, in itself, provide ample scope for a second book. 


\section{Acknowledgements}

We would like to thank the London Business School and Oxford Polytechnic for providing us with the time and institutional support to write this book. In the course of our work we have been helped by many people in the IT industry, government and academia who have given generously of their time in allowing us to interview them. Several people also took time to read and comment upon chapters, and we would like to thank the following in particular: Professor Tony Hoare, Professor Roger Needham, Richard Ennals, Tim Walker, Graham Ashe, John Hendry, Richard Nobbs, and Stuart MacDonald. We also would like to express our thanks to those who have given permission to reproduce the copyright material in the book.

We are also very grateful to Mrs Kathleen Rothwell, who diligently proof-read the book for us. Any errors which remain are, of course, our own.

Oxford

April 1986

Paul JowetT MARgARET RothWELL 


\section{Abbreviations and Acronyms}

ACARD Advisory Council on Applied Research and Development

AI

AT\&T

BAe

BT

BTG

CADDIA

$\mathrm{CD}-\mathrm{ROM}$

CEPT

CGR

CSA

DARPA

DBS

DEC

DES

DM

DoD

DoI

DTI

ECU

EEC

ESPRIT

ETL

FGCS

GEC

GLC

IBM

IC

ICL

ICOT

ICT

IKBS

IPR

IRC

IT
Artificial Intelligence

American Telephone and Telegraph

British Aerospace

British Telecom

British Technology Group

Cooperation in Automation of Data and Documentation for Imports/Exports and Agriculture

Compact Disk - Read Only Memory

Conférence Européene des Administrations des Postes et des Télecommunications

Compagnie Générale de Radiologie

Computer Services Association (UK)

Defence Advanced Research Projects Agency (USA)

Direct Broadcasting by Satellite

Digital Equipment Corporation (USA)

Department of Education and Science (UK)

Deutsche Mark

Department of Defense (USA)

Department of Industry, pre-1983 (UK)

Department of Trade and Industry, post-1983 (UK)

European Currency Unit

European Economic Community

European Strategic Programme of Research and Development in Information Technology

Electrotechnical Laboratory (Japan)

Fifth Generation Computer Society (Japan)

General Electric Company (UK)

Greater London Council

International Business Machines (USA)

Integrated Circuit

International Computers Limited (UK)

Institute for Fifth Generation Computer Technology (Japan)

International Computers and Tabulators (UK)

Intelligent Knowledge Based Systems

Intellectual Property Rights

Industrial Reorganisation Corporation (UK)

Information Technology 
ITT

JECC

JEIDA

JVC

K

LSE

MCC

MEP

MISP

MIT

MITI

MMI

MoD

NCR

NEB

NEC

NEDC

NTT

PABX

PIPS

PROLOG

QC

R\&D

RAM

RCA

SIA

SERC

SNA

SRC

STARS

STC

STELLA

UK

US(A)

VCR

VHS

VHSIC

VLSI
International Telephone and Telegraph

Jabanese Electronics and Computer Company

Japanese Electronics Industry Development Association

Victor Company of Japan (subsidiary of Matsushita)

1000 bits

London School of Economics

Microelectronics and Computer Technology Corporation

Member of the European Parliament

Microelectronics Industry Support Programme

Massachusetts Institute of Technology

Ministry of International Trade and Industry (Japan)

Man Machine Interface

Ministry of Defence (UK)

National Cash Register (USA)

National Enterprise Board (UK)

Nippon Electric Company (Japan)

National Economic Development Council (UK)

Nippon Telephone and Telegraph (Japan)

Private Branch Exchange

Pattern Information Processing Project (Japan)

AI Programming Language

Queen's Counsel

Research and Development

Random Access Memory

Radio Corporation of America

Semiconductor Industry Association (USA)

Science and Engineering Research Council (UK)

Systems Interconnect Architecture

Semiconductor Research Cooperative (USA)

Software Technology for Adaptable and Reliable Systems (USA)

Standard Telephone and Cable (UK)

High Speed Data Transmission Project (EEC)

United Kingdom

United States (of America)

Video Cassette Recorder

JVC's VCR system

Very High Speed Integrated Circuit

Very Large Scale Integration 